\title{
Exploring of the Human Capital depreciation of Ukrainian labor migrants abroad: results of a survey
}

\author{
Dr. Oksana Koshulko
}

\author{
Grant Holder of the Canadian Institute of Ukrainian Studies (CIUS), Ph.D. in Economic Sciences, \\ Associate Professor, a visiting fellow at the Center for Social and Economic Research (CASE), \\ Warsaw, Poland \\ oksana.koshulko@case-research.eu
}

\begin{abstract}
Keywords: Model of Human Capital depreciation, labor migrants, host countries, Human Capital
\end{abstract} depreciation rate, skilled workers, Brain Waste, survey

\begin{abstract}
The article presents the Model of Human Capital depreciation of labor migrants abroad and the depreciation of the existing amount of Human Capital of labor migrants in host countries.

The research also presents results of the survey, conducted in the Ternopil region of Ukraine among ex-labor migrants and children of labor migrants, which confirmed the Human Capital depreciation of Ukrainian labor migrants abroad.

The study also shows an example of computation of the Human Capital depreciation of a skilled worker who works as a labor migrant in a host country, and for this example uses the Human Capital depreciation rate by Spanish scientists M. Arrazola and J. Hevia.
\end{abstract}

\section{Introduction}

The Human Capital of skilled workers is a most important wealth for countries seeking to develop. Therefore, it is very important that these countries accumulate and use the Human Capital of skilled workers effectively for future profit and development. This subject is very topical and numerous scientists have studied Human Capital, Migration, and Education in the $20^{\text {th }}$ century, such as G. Becker [2], C. Dustmann [9], etc. and those continuing to study in $21^{\text {st }}$ century include M. Beinea, C. Defoortb, F. Docquier [3], I. Cieślak [4], S. Contreras [5], M. Dobija [6-8], B. Lowell [13], D. McFadden [14], L. Salmonsson, O. Mella [15], S.Weber [16], etc.

Sometimes skilled workers move abroad for specific reasons and if these workers cannot work abroad in their own professions, their Human Capital depreciates very quickly. In this case these skilled professional workers, who worked professionally in their home countries but cannot continue their careers abroad, will have Brain Waste, which is very negative not only for the host countries and their countries of origin, but primarily it is bad for them. So, my research is about the Human Capital depreciation of skilled workers - current labor migrants in host countries. Therefore I created the Model of the Human Capital depreciation of labor migrants abroad with the Human Capital depreciation rate $1.2 \%$ per year.

\section{The Model}

Skilled workers who come to host countries to work as labor migrants have a certain amount of Human Capital at their moment of arrival, but if these skilled workers do not have opportunities to work as professionals abroad over time, their Human Capital depreciates. I have created the Model of Human Capital depreciation of labor migrants abroad and I have denoted this Human Capital of labor migrants in host countries as $\mathrm{HC}^{\mathrm{h}}$. At the moment when these skilled workers arrive in their host countries, the process of their Human Capital depreciation has not started and this amount of the Human Capital may be denoted as $100 \%(1)$ : 
$H C^{h}=100 \%$,

where $\mathrm{HC}^{\mathrm{h}}$ is denoted the Human Capital of the labor migrants is at the moment of arrival in host countries;

and $100 \%$ is the specific amount of their Human Capital. If labor migrants do not work professionally in host countries, their Human Capital can depreciate.

I also can denote the Human Capital of labor migrants at the moment of their arrival in host countries as $1(2)$.

$H C^{h}=100 \%=1$,

where $\mathrm{HC}^{\mathrm{h}}$ is the denoted Human Capital of labor migrants at the moment of their arrival in host countries;

and $100 \%$ or 1 is the specific amount of the Human Capital of labor migrants at the moment of their arrival.

According to the research by Arrazola, M. and Hevia, J. [1], the depreciation rates of human capital is around $1-1.5 \%$ per year. In my model I have estimated a human capital depreciation rate of around $1.2 \%$ per year and $0.1 \%$ per month.

Using these rates I assume that labor migrants, who do not have opportunities to work in their own professions in host countries, lose $0.1 \%$ from their existing amount of their Human Capital per month. Therefore the formula for depreciation of the Human Capital $\left(\mathrm{HC}^{\mathrm{d}}\right)$ of labor migrants in host countries per month will be (3):

$H C^{d}=1-(1 \times 0,001)$

where $\mathrm{HC}^{\mathrm{d}}$ is the depreciation of the Human Capital of migrants in host countries per month;

$0.1 \%$ is the depreciation rate of existing amount of the Human Capital of labor migrants per month.

In this case the formula for depreciation of Human Capital $\left(\mathrm{HC}^{\mathrm{d}(\text { year) }}\right)$ of labor migrants in host countries per year will be (4):

$H C^{d(\text { year })}=1-1 \times(12 \times 0,001)=1-1 \times 0,012$,

where $\mathrm{HC}^{\mathrm{d}(\mathrm{year})}$ is the depreciation of the Human Capital of labor migrants in host countries per year;

$0.1 \%$ is the depreciation rate the existing amount of their Human Capital per month.

Therefore, over every 12 month period labor migrants will lose around $1.2 \%$ of their existing Human Capital.

The residence time of labor migrants in host countries is different, and in the formula of depreciation of the Human Capital $\left(\mathrm{HC}^{\mathrm{d}(\mathrm{n})}\right)$ of labor migrants in a host country it will be (5):

$H C^{d(n)}=1-1 \times(N \times 0,001)$,

where $H C^{\mathrm{d}(\mathrm{n})}$ is the depreciation of the Human Capital of labor migrants in host countries per undefined time;

$\mathrm{N}$ is number of months of residence of the labor migrants in host countries.

\section{Specific reasons that forced skilled workers from Ukraine to work as unskilled workers} abroad

As I noted already, skilled workers move abroad for specific reasons and if these workers cannot work abroad in their own professions, their Human Capital depreciates very quickly. What specific reasons can force skilled workers from Ukraine to work in host countries and to work there as unskilled workers? 
In order to explore these reasons a survey was conducted among ex-labor migrants and children of current labor migrants. 196 interviewees participated in this survey, and they gave the main reasons for Ukrainian labor migration as: unemployment (41.02\%); low wages $(16.61 \%)$; the need to acquire real estate $(11.53 \%)$; poverty $(10.51 \%)$; payment for the education of children in universities $(5.42 \%)$; debts $(5.08 \%)$; all reasons together $(9.15 \%)$; and desire for a better standard of living $(0.68 \%)$.

\section{Host countries for Ukrainian labor migrants and their professions abroad}

There were 360 replies to the survey from 196 interviewees and these replies showed that Ukrainian labor migrants work in Italy, Spain, Russia, Portugal, Poland, Czech Republic, Germany, USA, Greece, Belarus, UK, Canada, Sweden, Israel, Belgium, Ireland, Norway, Latvia, Lithuania, Turkey, Austria (Table 1).

Table 1 - Host countries for Ukrainian labor migrants according to the results of the survey in the Ternopil region of Ukraine in 2013.

\begin{tabular}{|l|l|l|l|}
\hline Countries & $\%$ & Countries & $\%$ \\
\hline Italy & 25,56 & USA & 8,61 \\
\hline Spain & 10,28 & Greece & 0,67 \\
\hline Russia & 15,28 & Belarus & 0,83 \\
\hline Portugal & 4,44 & UK & 2 \\
\hline Poland & 18,61 & Canada & 0,83 \\
\hline Czech Republic & 5,56 & Sweden & 0,28 \\
\hline Germany & 5,83 & Other & 1,22 \\
\hline
\end{tabular}

As seen from the Table 1, the following countries are in the top three host countries for Ukrainian labor migrants Italy - $25.56 \%$ (predominantly female migration); Poland - $18.61 \%$ (male and female migration); and Russia $15.28 \%$ (predominantly male migration).

Among the top three unskilled professions of Ukrainian labor migrants in host countries are builders (31.61\% from 310 responds); cleaners (26.77\%); and nurses/carers for the elderly and sick people (Italian - "badante") - (19.68\%). Ukrainian labor migrants also work abroad as sellers, health workers in hospitals, unskilled workers in different areas including agriculture, waiters, cooks, but $2.37 \%$ of these migrants, relatives of respondents, have a Ph.D Degree; $35.97 \%$ have a Graduate Degree; and $58.50 \%$ have a College Degree, etc.

In addition these labor migrants work in these professions long enough to confirm a hypothesis about the Human Capital depreciation because these migrants stay and work abroad for many years: $23.11 \%$ of relatives of respondents work abroad for 10 years and more; for $9-10$ years $-9.43 \%$; 6-8 years - 22.64\%; $3-5$ years - 20.28\%; $1-3$ years - $24.53 \%$. In these cases I have every reason to confirm the Human Capital depreciation of these labor migrants.

\section{An example of using the Model of depreciation of the Human Capital of labor migrants}

With the help of the Model of depreciation of Human Capital of labor migrants in host countries, the amount of the Human Capital depreciation per month $\left(\mathrm{HC}^{\mathrm{d}}\right)$ and per year $\left(\mathrm{HC}^{\mathrm{d}(\text { year) }}\right)$ of a skilled worker who is a current labor migrant will be computed. For this computation it is necessary to know the amount of the Human Capital $\left(\mathrm{HC}^{\mathrm{h}}\right)$ of this skilled worker who is a current labor migrant at the moment of arrival in a host country. How is it possible to compute this $\left(\mathrm{HC}^{\mathrm{h}}\right)$ ?

In my opinion via two methods:

- The first method is the Human Capital Theory by Mieczyslaw Dobija, based on computation of the human capital according to minimum wages, monthly cost of living, the human capital capitalized at the rate of $8 \%$ etc. $[4,6,7,8]$. This theory gives the human capital model by Mieczyslaw Dobija as (6): 
$H(T, p)=K(p)$,

where $\mathrm{H}(\mathrm{T}, \mathrm{p})$ denotes human capital of a skilled worker with $\mathrm{T}=0$ years of professional work; and $p=0.08$ is the economic constant which serves as the capitalization rate.

$\mathrm{K}(\mathrm{p})$ denotes the capitalized cost of living (future value) throughout the period, ending at the moment mandatory education is completed.

- The second method is my Human Capital Theory $[10,11,12]$ based on computation of the sum of all investments in human capital of a skilled worker during a period of study and a professional career (7):

$$
H C=\sum_{i=1}^{n} I_{i}
$$

where HC denotes Human Capital of a skilled worker;

$\mathrm{I}_{\mathrm{i}}$ is the sum of all investments in human capital of a skilled worker, in the education of this skilled worker, professional training, health care, raising the cultural and information level and the amount of wages as investments in the production of the human capital of this skilled worker for a certain period (n) of time.

For the Model depreciation of the Human Capital of labor migrants in host countries, I will use the amount of the Human Capital $\left(\mathrm{HC}^{\mathrm{h}}\right)$ of the skilled worker that I computed before [11] with the help of the Human Capital Theory by Mieczyslaw Dobija [4, 6, 7, 8], and this computed amount of the Human Capital $\left(\mathrm{HC}^{\mathrm{h}}\right)$ in money equivalent is 448 054.7 UAH [11] (8):

$$
H C^{h}=448054,7=100 \%=1,
$$

According to the research of M. Arrazola and J. Hevia [1], depreciation rates of human capital are of around 1-1.5\% per year. In this model I will use a depreciation rate of human capital of around $1.2 \%$ per year and $0.1 \%$ per month.

Therefore, suppose that labor migrants, if they do not have the opportunity to work in their own professions in host countries, can lose $0.1 \%$ from their existing amount of Human Capital per month, in this case the formula of depreciation of the Human Capital $\left(\mathrm{HC}^{\mathrm{d}}\right)$ of labor migrants in host countries per month will be (9):

$$
H C^{d}=448054,7-(448054,7 \times 0,001)=448054,7-448,0547=447606,6
$$

where $\mathrm{HC}^{\mathrm{d}}$ is the depreciation of the Human Capital of a skilled worker, who is a current labor migrant in a host country, per month;

$0.1 \%$ or 0,001 is the depreciation rate of the existing amount of the Human Capital of a skilled worker, who is a current labor migrant, per month.

So, depreciation of the Human Capital a skilled worker - current labor migrant is 448,0547 UAH per month.

In this case the formula of depreciation of the Human Capital $\left(\mathrm{HC}^{\mathrm{d}(\text { year })}\right)$ of a skilled worker current labor migrant in a host country per year will be (10):

$$
H C^{d(\text { year })}=448054,7-(448054,7 \times(12 \times 0,001)=448054,7-5376,6564=442678,0436
$$

where $\mathrm{HC}^{\mathrm{d}(\mathrm{year})}$ is the depreciation of the Human Capital of a skilled worker, who is a current labor migrant in a host country, per year;

$0.1 \%$ or 0,001 is the depreciation rate of the Human Capital of a skilled worker, who is a current labor migrant, per month. 
So, depreciation level of the Human Capital of a skilled worker, who is a current labor migrant, is 5376,6564 UAH per year, and every 12 months this skilled worker, a current labor migrant, may lose around $1.2 \%$ of existing amount of the Human Capital or in money equivalent this is 5376,6564 UAH. Over eight years (for example) depreciation of the existing amount of the Human Capital of a current labor migrant may be around $9,6 \%$ or $43013,2512 \mathrm{UAH}$ in money equivalent (11) (Fig. 1).

$$
H C^{d(\text { year })}=448054,7-(448054,7 \times 0,096)=448054,7-43013,2512=405041,45
$$

So, if skilled professional workers, who worked as professionals in their countries of origin, but cannot continue their careers abroad, work as labor migrants in host countries, there will be Brain Waste for them, for their host countries and their countries of origin. Very often these skilled workers, professionals in the past, even when they return to their countries of origin, cannot work in their previous professions, which is an even worse situation for them. Of course, during a period of labor migration abroad, labor migrants, professionals in the past, may develop new skills and knowledge, but, unfortunately, labor migrants often perform unskilled work abroad.

In my opinion, the biggest problems for skilled workers seeking work as professionals in host countries are language barriers, problems with confirmation of diplomas in host countries, lack of competitive knowledge and skills on international labor markets.

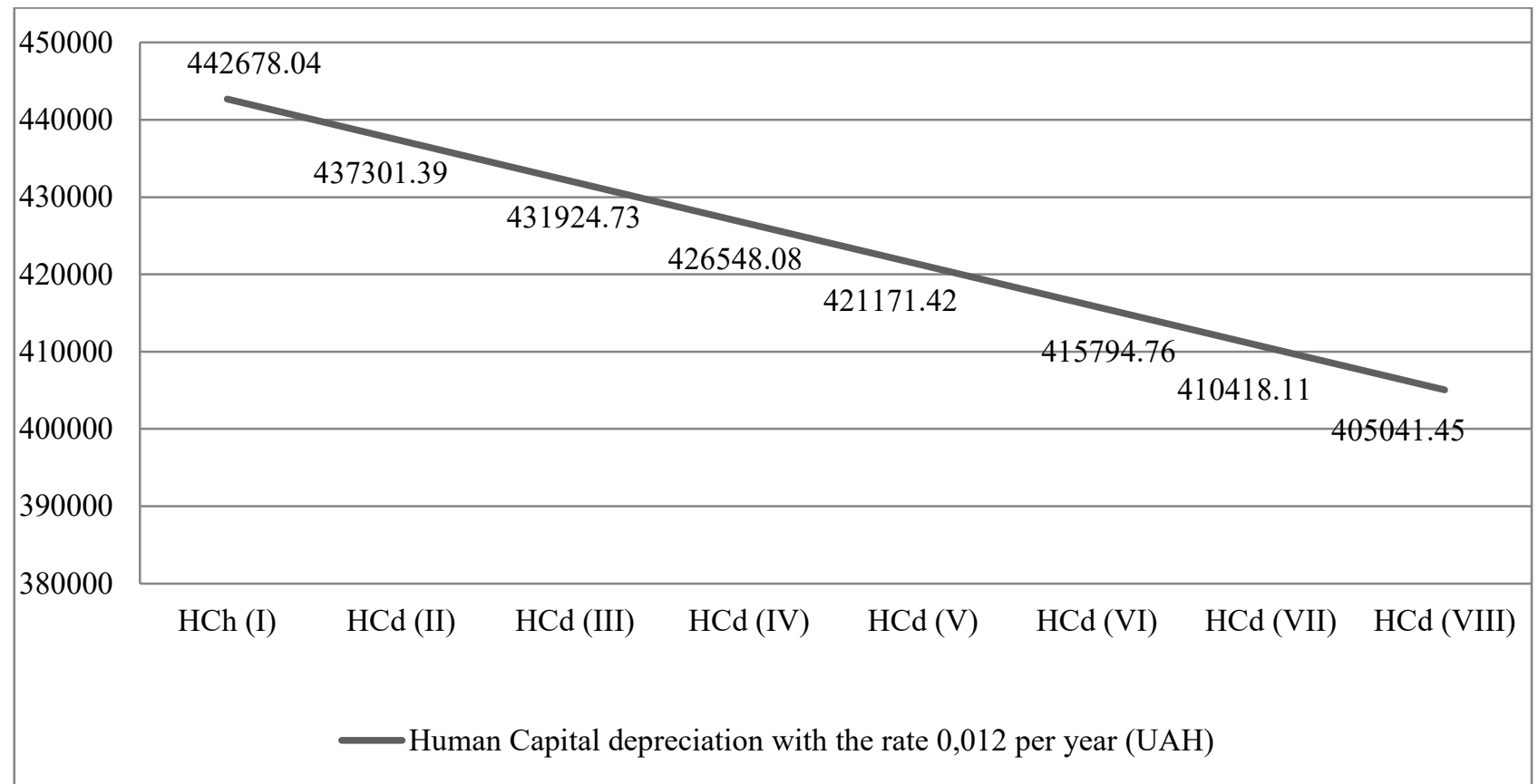

Figure 1: An example of depreciation of the Human Capital of a skilled worker, who is a current labor migrant in a host country during eight years (for example).

\section{Conclusions}

Currently the movement of migrants from one country to other is a normal process as migrants try to find better opportunities for life and work. However, when skilled workers, for whatever reasons, are forced to move abroad and to work as unskilled workers, there is a very big problem of Brain Waste for all sides, for skilled workers, who were professionals in the past, for their country of origin and for their host countries too. Very often these skilled workers, professionals in the past, when they return to their country of origin, find that they cannot work in their previous professions, which is a worse situation for them. Of course, during a period of labor migration abroad, labor migrants, professionals in the past, can develop new skills and knowledge, but, unfortunately, labor migrants often perform unskilled work abroad. In my opinion, the biggest problems for skilled 
workers seeking work as professionals in host countries are language barriers, problems with confirmation of diplomas in host countries, lack of competitive knowledge and skills on international labor markets.

The research also presents results of the survey, conducted in the Ternopil region of Ukraine among ex-labor migrants and children of labor migrants, which confirmed the Human Capital depreciation of Ukrainian labor migrants abroad. 196 interviewees participated in this survey, and they have given the main reasons for Ukrainian labor migration as: unemployment; low wages; the need to acquire real estate; poverty; payment for the education of children in universities; debts; all reasons together; and the desire for a better standard of living.

The top three host countries for Ukrainian labor migrants are following countries: Italy, Poland, and Russia. Among the top three unskilled professions of Ukrainian labor migrants in host countries are: builders, cleaners, and nurses/carers for the elderly and sick people. Ukrainian labor migrants also work abroad as sellers, health workers in hospitals, unskilled workers in different areas including agriculture, waiters, cooks, but $2.37 \%$ of these migrants, relatives of respondents, have a $\mathrm{Ph} . \mathrm{D}$ Degree; 35.97\% have a Graduate Degree; and 58.50\% have a College Degree, etc.

In addition these labor migrants work in these unskilled professions long enough to confirm a hypothesis about the Human Capital depreciation because these migrants stay and work abroad for many years: $23.11 \%$ of relatives of respondents work abroad for 10 years and more; for 9-10 years $9.43 \%$; 6-8 years - $22.64 \%$; 3-5 years - $20.28 \%$; $1-3$ years $-24.53 \%$. In these cases I have every reason to confirm the Human Capital depreciation of these labor migrants.

\section{Acknowledgment}

This research has been accomplished under the auspices of the Canadian Institute of Ukrainian Studies (CIUS), University of Alberta, Canada and the Center for Social and Economic Research (CASE), Warsaw, Poland, and the newspaper "Kolos" of the Ternopil region, Ukraine. Their support is herewith gratefully appreciated and acknowledged.

\section{References}

[1] M. Arrazola, J, Hevia, More on the estimation of the human capital depreciation rate. Applied Economics Letters. 11 (3), (2004) 145-148. DOI:10.1080/1350485042000203742.

[2] G.S. Becker, Human Capital: A Theoretical and Empirical Analysis with Special Reference to Education, National Bureau of Economic Research. (1964).

[3] M. Beinea, C. Defoortb, F. Docquier, Skilled migration, human capital inequality and convergence. Center for Research and Analysis of Migration (CReAM). (2005). Information on http://www.cream-migration.org/publicationsdiscussionpapers.php?year=2005.

[4] I. Cieślak, M. Dobija, Teoretyczne podstawy rachunkowości kapitału ludzkiego, Zeszyty Naukowe, Uniwersytet Ekonomiczny w Krakowie. 735 (2007) 5-24.

[5] S. Contreras, The Influence of Migration on Human Capital Development International Economic Journal. 27(3), (2013) 1-20. DOI:10.1080/10168737.2012.659277.

[6] M. Dobija, Teoria pomiaru kapitału i zysku. Wydawnictwo Uniwersytetu Ekonomicznego w Krakowie, Kraków. (2010): 200.

[7] M. Dobija, Labor Productivity vs. Minimum Wage Level. Modern Economy. 2 (2011) 780787. Information on http://dx.doi.org/10.4236/me.2011.25086.

[8] M. Dobija, Political Reforms Based on a Human Capital Research Programme, Argumenta Oeconomica Cracoviensia. 8 (2012) 9-29.

[9] C. Dustmann, Temporary Migration, Human Capital, and Language Fluency of Migrants. The Scandinavian Journal of Economics Volume. 101 (2), (1999) 297-314. 
[10]O. Koshulko, Human Resources Management at Food Retail Industry. - Manuscript. The dissertation on gaining the Economic Sciences Candidate degree on the speciality 08.00.04 economics and management of enterprises. - National University of Food Technologies, Kyiv, 2008.

[11]O. Koshulko, The Study of the Minimum Wage in Ukraine and its Impact on the Development of Human Capital, The economic analysis the theory and practice, Moscow, Russian Federation. 7(262), (2012). 58-63.

[12] O. Koshulko, The "Value of Life and Labor" of Ukrainian Migrants Abroad, International Letters of Social and Humanistic Sciences, SciPress Ltd., Switzerland. 59 (2015) 1-8. doi:10.18052/www.scipress.com/ILSHS.59.1.

[13]B.L. Lowell, Skilled Migration Abroad or Human Capital Flight? Migration Policy.org. (2003). Information on http:/www.migrationpolicy.org/article/skilled-migration-abroad-or-humancapital-flight.

[14]D. McFadden, Human Capital Accumulation and Depreciation. Applied Economic Perspectives and Policy. 30(3), (2008) 379-385. doi: 10.1111/j.1467-9353.2008.00411.x.

[15]L. Salmonsson, O. Mella, Cultural demands on skilled immigrants, a devaluation of human capital. The case of immigrant physicians in Sweden. Nordic Journal of Migration Research. 3(1), (2013). 3-9. DOI: 10.2478/v10202-012-0008-6.

[16] S.Weber, Human capital depreciation and education level, International Journal of Manpower, 35(5), (2014) 613-642. 